D) Check for updates

Cite this: Chem. Commun., 2021, 57,875

Received 20th October 2020,

Accepted 16th December 2020

DOI: $10.1039 / \mathrm{d} 0 \mathrm{cc} 06983 \mathrm{c}$

rsc.li/chemcomm

\section{Electron transfer within $\beta$-diketiminato nickel bromide and cobaltocene redox couples activating $\mathrm{CO}_{2} \dagger+$}

\author{
Philipp Zimmermann, ${ }^{a}$ Alexander F. R. Kilpatrick, (iD a Deniz Ar, ${ }^{a}$ Serhiy Demeshko, \\ Beatrice Cula (iD ${ }^{a}$ and Christian Limberg (iD *a
}

\begin{abstract}
Reduction of $\beta$-diketiminato nickel(II) complexes ( $\mathrm{L}^{\mathrm{tBu}} \mathrm{Ni}$ ) to the corresponding nickel( $(1)$ compounds does not require alkali metal compounds but can also be performed with the milder cobaltocenes. $\mathrm{L}^{\mathrm{tBu}} \mathrm{NiBr}$ and $\mathrm{Cp}_{2} \mathrm{Co}$ have rather similar redox potentials, so that the equilibrium with the corresponding electron transfer compound [ $\left.{ }^{\mathrm{tBu}}{ }^{\mathrm{i}} \mathrm{Br}\right]\left[\mathrm{Cp}_{2} \mathrm{Co}^{\prime \prime \prime}\right]$ (ETC) clearly lies on the side of the starting materials. Still, the ETC portion can be used to activate $\mathrm{CO}_{2}$ yielding a mononuclear nickel(II) carbonate complex and ETC can be isolated almost quantitatively from the solutions through crystallisation. The more negative reduction potential of $\mathrm{Cp}_{2}{ }_{2} \mathrm{Co}$ shifts the equilibrium formed with $\mathrm{L}^{\mathrm{tBu}} \mathrm{NiBr}$ strongly towards the ETC and accordingly the reaction of such solutions with $\mathrm{CO}_{2}$ is much faster.
\end{abstract}

Monovalent nickel has the reductive power to activate substrates by injecting an electron or by transferring electron density. ${ }^{1}$ A couple of nickel enzymes are known or proposed to involve nickel(I) intermediates in developing functions like the conversion of carbon oxides. ${ }^{1}$ Consistently, in the last decade the $\beta$-diketiminato nickel(I) moiety has demonstrated its potential to activate small molecules, such as $\mathrm{CO}_{2}$ and $\mathrm{CO}$, but also $\mathrm{N}_{2}, \mathrm{H}_{2}$, $\mathrm{P}_{4}, \mathrm{SF}_{6}, \mathrm{O}_{2}$, formate, NO, Azides and organonitro and -nitroso compounds. ${ }^{1-16}$ Typically, it is generated by the reaction of a $\beta$-diketiminato nickel(II) bromido precursor with elemental sodium or potassium, $\mathrm{KC}_{8}$ or $\mathrm{Na} / \mathrm{Hg}$, and subsequently it has three possibilities to reach a stable coordinative saturation: (i) it binds a solvent donor molecule or a donor from the gas phase, like $\mathrm{N}_{2}$; (ii) the alkali metal halide generated concomitantly remains in the coordination sphere; (iii) the aryl ring of a second

\footnotetext{
${ }^{a}$ Humboldt-Universität zu Berlin, Institut für Chemie, Brook-Taylor-Str. 2, 12489 Berlin, Germany. E-mail: christian.limberg@chemie.hu-berlin.de

${ }^{b}$ Universität Göttingen, Institut für Anorganische Chemie, Tammannstr. 4, D-37077 Göttingen, Germany

$\dagger$ Dedicated to Professor Dr Wolfgang Kaim on occasion of his 70th birthday. ‡ Electronic supplementary information (ESI) available: Experimental section, additional figures and X-Ray crystallographic data. CCDC 2023970, 2023971, 2024643. For ESI and crystallographic data in CIF or other electronic format see DOI: $10.1039 / \mathrm{d} 0 \mathrm{cc} 06983 \mathrm{c}$
}

molecule is coordinated so that a dimerization occurs. ${ }^{4,9,17}$ A further option becomes conceivable, if reductants are used that produce a weakly coordinating cation, namely, the preservation of the $\beta$-diketiminato nickel bromide core. We were interested to examine the behaviour of such a system, especially in a redox regime that is not as harsh as under conditions where alkali metals are used as reductants, bearing in mind that nickel enzymes, which reductively activate $\mathrm{CO}$ or $\mathrm{CO}_{2}$, also work at comparatively mild potentials.

For the selection of suitable reductants, the half-wave potentials had to be considered. In THF solution $\mathrm{L}^{t \mathrm{Bu}} \mathrm{NiBr}$ $\left(\mathrm{L}^{t \mathrm{Bu}}=\left[\mathrm{HC}\left(\mathrm{C}\left(\mathrm{CMe}_{3}\right) \mathrm{NC}_{6} \mathrm{H}_{3}\left({ }^{\mathrm{i}} \mathrm{Pr}\right)_{2}\right)_{2}\right]^{-}\right)$exhibits a reversible redox event at $-1.37 \mathrm{~V}\left(v s . \mathrm{Fc} / \mathrm{Fc}^{+}\right.$) that corresponds to the $\mathrm{Ni}^{\mathrm{II}} / \mathrm{Ni}^{\mathrm{I}}$ redox couple (see Fig. S3, ESI $\$$ ). Contemplating the chemical conversion of the nickel(II) complex to a reduced product, the Nernst equation for reversible electron-transfer processes requires the reductant to have a redox potential that is $0.118 \mathrm{~V}$ more negative to achieve a yield of $91 \%$. The formal potentials of $\mathrm{Cp}_{2} \mathrm{Co}$ and $\mathrm{Cp}^{*}{ }_{2} \mathrm{Co}$ in THF are $-1.33^{18} \mathrm{~V}$ and $-1.85^{19} \mathrm{~V}\left(v s . \mathrm{Fc} / \mathrm{Fc}^{+}\right)$, respectively. Hence, in the case of $\mathrm{Cp}_{2}{ }_{2} \mathrm{Co}$ an almost quantitative electron transfer was to be expected. However, $\mathrm{Cp}_{2}$ Co was anticipated to represent an interesting case, too, as the formal potentials of both reactants are almost at the same level, so that the corresponding redox equilibrium should be subject to subtle influences.

Combining toluene solutions of $\mathrm{L}^{t \mathrm{Bu}} \mathrm{NiBr}$ and $\mathrm{Cp}^{*}{ }_{2} \mathrm{Co}$ led to red solutions, from which upon standing for $1 \mathrm{~h}$ a brown crystalline solid precipitated. Single crystal X-ray analysis combined with spectroscopic data revealed that it corresponded to the expected product $\left[\mathrm{L}^{t \mathrm{Bu}} \mathrm{Ni}{ }^{\mathrm{I}} \mathrm{Br}\right]\left[\mathrm{Cp}^{*}{ }_{2} \mathrm{Co}^{\mathrm{III}}\right], \mathbf{1}$. The determined structure (Fig. 1) features a $\mathrm{L}^{t \mathrm{Bu}} \mathrm{NiBr}$ beside a $\mathrm{Cp}^{*}{ }_{2} \mathrm{Co}$ entity, and the relevant bond lengths and angles indicate that the electron has been transferred from Co to Ni, i.e. that $\mathbf{1}$ corresponds to an ionic compound: The bond distances around the nickel centre of the $\left[\mathrm{L}^{t \mathrm{Bu}} \mathrm{NiBr}\right]^{-}$anion in $1(d(\mathrm{Ni}-\mathrm{N})=1.895(4), 1.904(4) \AA$; $d(\mathrm{Ni}-\mathrm{Br})=2.3447(8) \AA)$ are significantly longer than those found in the neutral complex $\mathrm{L}^{t \mathrm{Bu}} \mathrm{NiBr}$ (see Fig. S16 (ESI $\ddagger$ ), 


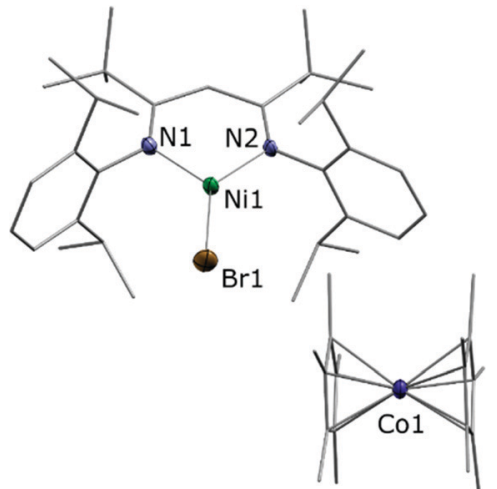

Fig. 1 Molecular structure of $\left[\mathrm{L}^{\mathrm{tBu}} \mathrm{NiBr}\right]\left[\mathrm{Cp}^{*}{ }_{2} \mathrm{Co} \cdot 3 \mathrm{C}_{7} \mathrm{H}_{8}\right.$. Hydrogen atoms are omitted for clarity. Selected bond lengths $/ \AA$ and angles $/{ }^{\circ}$ : N1-Ni1 1.895(4), N2-Ni1 1.904(4), Ni1-Br1 2.3447(8), N2-Ni1-N1 98.67(16), N1-Ni1-Br1 134.78(12), N2-Ni1-Br1 126.53(12), ave. Co- $\mathrm{C}_{\mathrm{Cp}}=2.051(6)$, ave. Co-Cp $\mathrm{p}_{\mathrm{cent}}=$ 1.655(3).

$d(\mathrm{Ni}-\mathrm{N})=1.8112(16), \AA$ the range found for corresponding bonds in other $\mathrm{Ni}^{\mathrm{I}}$ complexes containing that $\beta$-diketiminato ligand., ${ }^{4,9}$ The bond distances involving the cobalt atom in 1 (ave. Co- $\mathrm{C}_{\mathrm{Cp}}=2.051(6) \AA$; Co-Cp $\mathrm{p}_{\text {cent }}=1.655(3) \AA$ ) are typical of those found in a decamethylcobaltocenium cation (e.g. $\left[\mathrm{Cp}^{*}{ }_{2} \mathrm{Co}\right]\left[\mathrm{PF}_{6}\right]$; ave. $\mathrm{Co}-\mathrm{C}_{\mathrm{Cp}}=2.053(3) \AA$; Co-Cp cent $=1.655(2) \AA) .{ }^{20}$ Consistently, the solid showed an EPR signal that matches well previous signals observed for $\mathrm{L}^{t \mathrm{Bu}} \mathrm{Ni}^{\mathrm{I}}$ complexes.

Astonishingly, the reaction between $\mathrm{L}^{t \mathrm{Bu}} \mathrm{NiBr}$ and $\mathrm{Cp}_{2} \mathrm{Co}$ proceeded similarly, despite the much milder reduction potential of $\mathrm{Cp}_{2} \mathrm{Co}$. As before a brown solid crystallised directly from the reaction solution when the latter was sufficiently concentrated, and a single crystal X-ray analysis revealed a product constitution consisting of a $\mathrm{L}^{t \mathrm{Bu}} \mathrm{NiBr}$ and a $\mathrm{Cp}_{2} \mathrm{Co}$ entity (Fig. 2). The Cp-Co distances (ave. Co- $\mathrm{C}_{\mathrm{Cp}}=2.026(5) \AA$; Co- $\left.-\mathrm{Cp}_{\text {cent }}=1.629(3) \AA\right)$ are consistent with those of a cobaltocenium cation $\left(\left[\mathrm{Cp}_{2} \mathrm{Co}\right]\left[\mathrm{PF}_{6}\right]\right.$; ave. $\mathrm{Co}-\mathrm{C}_{\mathrm{Cp}}=2.026(4) \AA$;

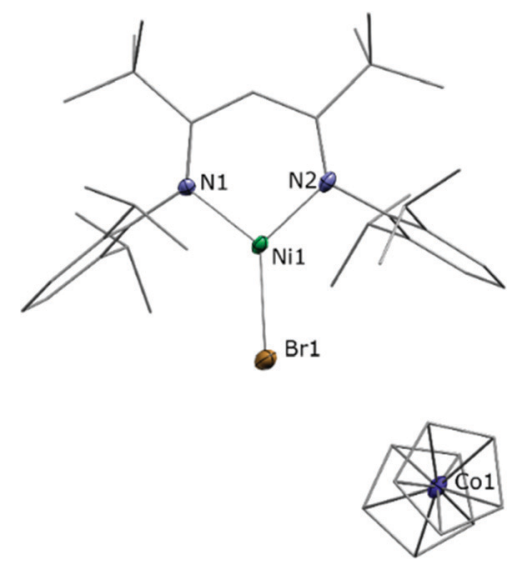

Fig. 2 Molecular structure of $\left[\mathrm{L}^{\mathrm{tBu}} \mathrm{NiBr}\right]\left[\mathrm{Cp}_{2} \mathrm{Co}\right]$. Hydrogen atoms are omitted for clarity. Selected bond lengths $/ \AA$ and angles $/^{\circ}$ : $\mathrm{N} 1-\mathrm{Ni1}$ 1.898(4), N2-Ni1 1.891(4), Ni1-Br1 2.3443(8), N2-Ni1-N1 99.18(17), N1-Ni1-Br1 130.55(12), N2-Ni1-Br1 130.26(12), ave. Co- $\mathrm{C}_{\mathrm{Cp}}=$ 2.026(5), ave. Co-Cp $p_{\text {cent }}=1.629(3)$.
Co-Cp $\left.\mathrm{p}_{\text {cent }}=1.637(5) \AA\right),{ }^{21}$ and for the same arguments as before again the structural data of the $\mathrm{L}^{t \mathrm{Bu}} \mathrm{NiBr}$ unit point to an ionic compound, i.e. $\left[\mathrm{L}^{t \mathrm{Bu}} \mathrm{Ni}^{\mathrm{I}} \mathrm{Br}\right]\left[\mathrm{Cp}_{2} \mathrm{Co}^{\mathrm{III}}\right], 2$.

Indeed SQUID magnetometry measurements are consistent with an $S=1 / 2$ system over the entire temperature range (between 2 and $295 \mathrm{~K}$, see Fig. S15, ESI $\$$ ), and EPR spectroscopy of polycrystalline 2 shows a signal typical for $\mathrm{L}^{t \mathrm{Bu}} \mathrm{Ni}^{\mathrm{I}}$ compounds.

Consequently, the electron transfer compound $\left[\mathrm{L}^{t \mathrm{Bu}} \mathrm{Ni}{ }^{\mathrm{I}} \mathrm{Br}\right]-$ $\left[\mathrm{Cp}_{2} \mathrm{Co}^{\mathrm{III}}\right]$ had precipitated in a clean manner from the reaction mixture. However, when the same red brown solid was dissolved, investigations performed with the solution revealed a rather different situation. Unlike solutions of $\mathbf{1}$ in toluene, which are red and lead to an intense EPR signal, toluene solutions of 2 are green brown at RT (Fig. S1, ESI $\ddagger$ ) and in the EPR spectrum no signal could be observed, which supports the case for a reverse of electron transfer: Resulting $\mathrm{L}^{t \mathrm{Bu}} \mathrm{Ni}^{\mathrm{II}} \mathrm{Br}$ is an even-spin system and does not show an EPR signal in the perpendicular mode, while for $\mathrm{Cp}_{2} \mathrm{Co}$ an EPR spectrum can only be expected at rather low temperatures, due to the fast relaxation of its excited state. ${ }^{22,23}$ Upon cooling toluene solutions of 2 , however, the colour brightens and eventually becomes comparable to that of 1 in toluene (Fig. S1, ESI + ). At the same time a characteristic $\mathrm{Ni}^{\mathrm{I}}$ signal starts to emerge with decreasing temperature (Fig. 3), pointing to an equilibrium as depicted in eqn (1) that can be influenced by the temperature.

$$
\mathrm{L}^{t \mathrm{Bu}} \mathrm{Ni}^{\mathrm{II}} \mathrm{Br}+\mathrm{Cp}_{2} \mathrm{Co}^{\mathrm{II}} \rightleftharpoons\left[\mathrm{L}^{t \mathrm{Bu}} \mathrm{Ni}^{\mathrm{I}} \mathrm{Br}\right]\left[\mathrm{Cp}_{2} \mathrm{Co}^{\mathrm{III}}\right]
$$

Integration of the EPR signals (in comparison to a standard) allowed the determination of the equilibrium constants at different temperatures (Fig. S14, ESI $\$$ ) and via the van’t Hoff equation a $\Delta H_{\mathrm{r}}^{\circ}$ of $-20.3 \mathrm{~kJ} \mathrm{~mol}^{-1}$ as well as a $\Delta S_{\mathrm{r}}^{\circ}$ of $-102.1 \mathrm{~J} \mathrm{~mol}^{-1} \mathrm{~K}^{-1}$ was determined, giving a $\Delta G_{\mathrm{r}}^{\circ}$ of $9.8 \mathrm{~kJ} \mathrm{~mol}^{-1}$.

Hence, at room temperature this equilibrium lies far on the left-hand side and the two components are largely uncoupled with less than $2 \%$ of electron transfer complex $\left[\mathrm{L}^{t \mathrm{Bu}} \mathrm{Ni} \mathrm{i}^{\mathrm{I}} \mathrm{Br}\right]$ $\left[\mathrm{Cp}_{2} \mathrm{Co}^{\mathrm{III}}\right], 2$, formed. However, apparently despite this small fraction the low solubility of 2 leads to its crystallisation and thus to the continuous shifting of the equilibrium to the right-hand

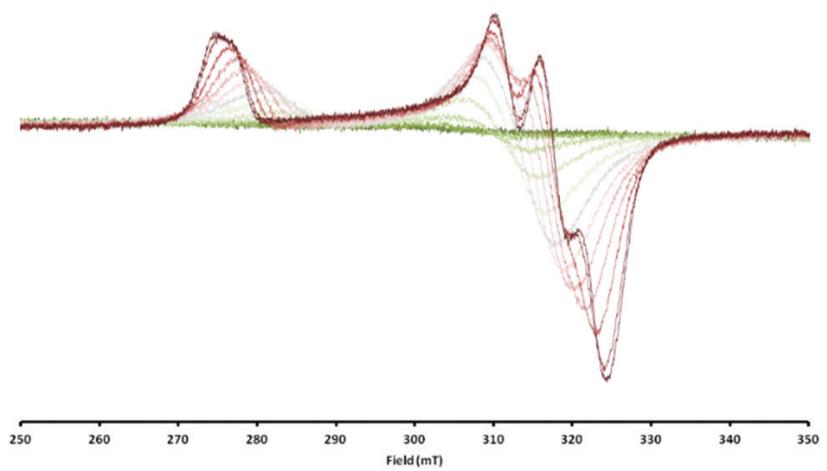

Fig. 3 Overlaid EPR spectra of $\left[{ }^{\mathrm{tBu}} \mathrm{NiBr}\right]\left[\mathrm{Cp}_{2} \mathrm{Co}\right]$ in toluene measured between $20{ }^{\circ} \mathrm{C}$ (dark green, silent) and $-95^{\circ} \mathrm{C}$ (dark red, up to $\sim 60 \%$ ). 


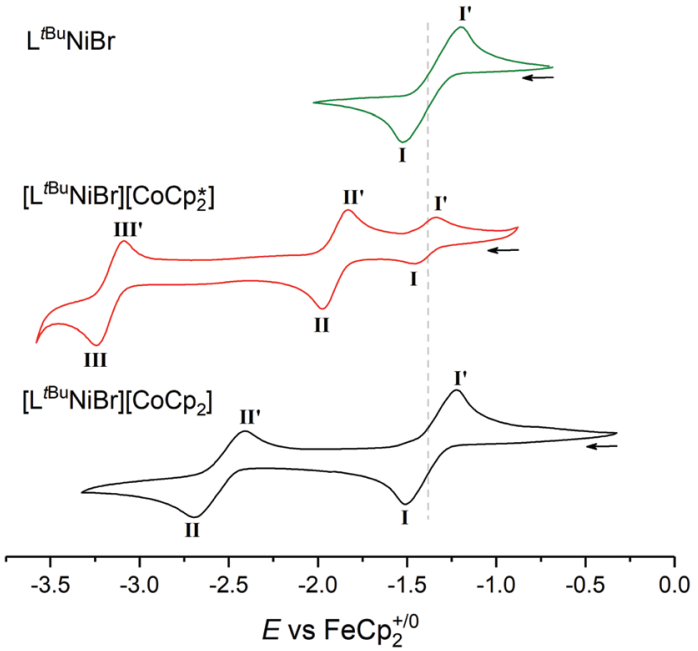

Fig. 4 Offset cyclic voltammograms of $\mathrm{L}^{\mathrm{tBu}} \mathrm{NiBr}$ (green), $\left[\mathrm{L}^{\mathrm{tBu}} \mathrm{NiBr}\right]\left[\mathrm{Cp}{ }_{2} \mathrm{Co}\right]$ (red) and [ $\left.\mathrm{L}^{\mathrm{tBu}} \mathrm{NiBr}\right]\left[\mathrm{Cp}_{2} \mathrm{Co}\right]$ (black) in THF/0.1 M $\left[{ }^{n} \mathrm{Bu}_{4} \mathrm{~N}\right]\left[\mathrm{PF}_{6}\right]$, scan rate $100 \mathrm{mV} \mathrm{s}^{-1}$. Dotted line denotes $\mathrm{Ni}^{1 / / /}$ couple.

side. In the solid state - removed from the equilibrium $\left[\mathrm{L}^{t \mathrm{Bu}} \mathrm{Ni} \mathrm{I} \mathrm{Br}\right]\left[\mathrm{Cp}_{2} \mathrm{Co}^{\mathrm{III}}\right]$ is stable as an ion-pair.

Naturally, it was of interest how such a solution behaves electrochemically in comparison to solutions of $\left[\mathrm{L}^{\mathrm{tBu}} \mathrm{NiBr}\right]$ and 1 (Fig. 4). While $\mathrm{L}^{t \mathrm{Bu}} \mathrm{Ni}^{\mathrm{II}} \mathrm{Br}$ shows the abovementioned single $\mathrm{Ni}^{\mathrm{II}} / \mathrm{Ni}^{\mathrm{I}}$ redox event at $-1.37 \mathrm{~V}$ (process I), CV scans of 1 as expected show two further reversible events at more negative potentials. Process II is assigned to the $\mathrm{Co}{ }^{\mathrm{III}} / \mathrm{Co}^{\mathrm{II}}$ couple, while process III at $-3.16 \mathrm{~V}$ is typical for $\mathrm{Co}^{\mathrm{II}} / \mathrm{Co}^{\mathrm{I}}$ of $\mathrm{Cp}^{*}{ }_{2} \mathrm{Co}$. Consequently, three events should be expected for 2 , too, but the lower electron donating effect of $\mathrm{Cp}$ with respect to $\mathrm{Cp}^{*}$ for the cobaltocene means here the $\mathrm{Ni}^{\mathrm{II}} / \mathrm{Ni}^{\mathrm{I}}$ and $\mathrm{Co}^{\mathrm{II}} / \mathrm{Co}^{\mathrm{II}}$ events coincidentally overlap $\left(E_{1 / 2}^{(\mathrm{I})}=-1.37 \mathrm{~V}\right)$, and the $\mathrm{Co}^{\mathrm{II} / \mathrm{I}}$ event occurs at a more positive potential $\left(E_{1 / 2}^{(\mathrm{II})}=-2.55 \mathrm{~V}\right)$.

The increased current response of process I with respect to process II (average $i_{\mathrm{p}}^{(\mathrm{I})} / i_{\mathrm{p}}^{(\mathrm{II})}=1.2$ ) is consistent with this interpretation.

Finally, bearing in mind the background outlined in the introduction, the potential of $\mathbf{1}$ and 2 to activate $\mathrm{CO}_{2}$ was investigated. The nickel( $\mathrm{I})$ complex $\left[\mathrm{L}^{t \mathrm{Bu}} \mathrm{Ni}^{\mathrm{I}}-\mathrm{N}_{2}-\mathrm{Ni}^{\mathrm{I}} \mathrm{L}^{t \mathrm{Bu}}\right]$ containing a labile dinitrogen ligand had been found to reductively couple $\mathrm{CO}_{2}$ to give oxalate. ${ }^{2}$ After double reduction of $\left[\mathrm{L}^{t \mathrm{tBu}} \mathrm{Ni}^{\mathrm{I}}-\right.$ $\left.\mathrm{N}_{2}-\mathrm{Ni}^{\mathrm{I}} \mathrm{L}^{\mathrm{tBu}}\right]$ with two equivalents of potassium the resulting $\left[\mathrm{L}^{t \mathrm{tBu}} \mathrm{Ni}^{\mathrm{I}}-\mathrm{N}_{2}-\mathrm{Ni}^{\mathrm{I}} \mathrm{L}^{t \mathrm{Bu}}\right] \mathrm{K}_{2}$ had proved capable of cleaving $\mathrm{CO}_{2}$ to give nickel-bound $\mathrm{CO}$ and a carbonate complex $\left[\mathrm{L}^{t \mathrm{Bu}} \mathrm{Ni}^{\mathrm{II}}-\mathrm{CO}_{3}\right] \mathrm{K}$, which aggregates through interactions involving the potassium ions to yield a hexamer. ${ }^{2}$ As in $\mathbf{1}$ and $\mathbf{2}$ the nickel complex anion contains only one reducing equivalent, a reaction analogous to $\left[\mathrm{L}^{t \mathrm{Bu}} \mathrm{Ni}^{\mathrm{I}}-\mathrm{N}_{2}-\mathrm{Ni}^{\mathrm{I}} \mathrm{L}^{t \mathrm{Bu}}\right]$ with formation of oxalate appeared intuitively more likely, but instead of the readily dissociating neutral $\mathrm{N}_{2}$ ligand more strongly bound anionic bromido ligands are found in $\mathbf{1}$ and $\mathbf{2}$, so that the nickel centres are not similarly accessible. Indeed, this significantly altered the course of the reaction. Upon addition of $\mathrm{CO}_{2}$ to solutions of $\mathbf{1}$ in $\mathrm{C}_{6} \mathrm{D}_{6}$ or toluene, within a minute the mixture became cloudy and a microcrystalline solid precipitated. This was analyzed by

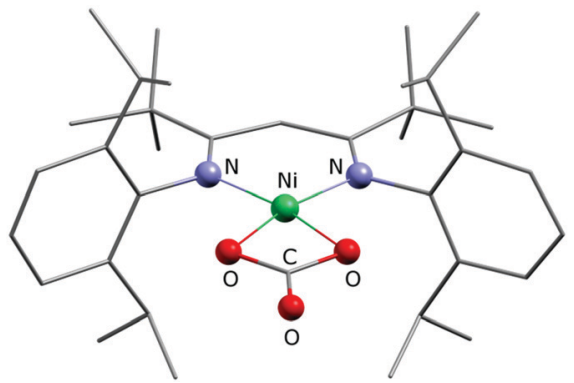

Fig. 5 Ball and stick drawing of the solid state structure of the $\left[\mathrm{L}^{\mathrm{tBu}} \mathrm{NiCO}_{3}\right]^{-}$anion in $\mathbf{3}$.

means of ATR-IR spectroscopy and while no $\mathrm{Ni}-\mathrm{CO}^{3}$ or oxalate ${ }^{2}$ species were detected, bands between 1550 and $1650 \mathrm{~cm}^{-1}$ were detected, indicating the formation of a carbonate product (further assignment is difficult due to band overlap). In contrast, reaction of 2 with $\mathrm{CO}_{2}$ took much longer and thus only after 30 minutes the solution started to become cloudy, which is reasonable, as 2 can only react out of an equilibrium, in which it exists as a minor component. However, the slow reaction rate led to the formation of a crystalline solid after storage for one week and a crystal structure analysis indeed revealed the formation of the mononuclear carbonate complex $\left[\mathrm{L}^{t \mathrm{Bu}} \mathrm{NiCO}_{3}\right]\left[\mathrm{Cp}_{2} \mathrm{Co}\right], 3$ (Fig. 5). Extensive efforts to grow high quality crystals remained without avail, so that the data quality does not permit a discussion of metric parameters, but the molecular structure determined and the constitution are without doubt. A carbonate anion is symmetrically coordinating the nickel centre in a square planar fashion, so that the structure of 3 is rather different as compared to the one of $\left\{\left[\mathrm{L}^{t \mathrm{Bu}} \mathrm{Ni}^{\mathrm{II}}-\mathrm{CO}_{3}\right] \mathrm{K}\right\}_{6}$, where the $\mathrm{K}^{+}$counterions actively participate in the structure construction and lead to aggregation to a hexanuclear complex. ${ }^{2,24,25}$ A similar outcome as in case of the reaction between 1 and $\mathrm{CO}_{2}$ was also revealed for 2 by ATR-IR spectroscopy (bands between 1550 and $1650 \mathrm{~cm}^{-1}$ ) and also in this case no $\mathrm{Ni}-\mathrm{CO}^{3}$ or oxalate ${ }^{2}$ complexes were detected.

Formation of 3 requires cooperation of two equivalents of $\mathbf{2}$, which activate one $\mathrm{CO}_{2}$ molecule, likely yielding in a $\mathrm{Ni}^{\mathrm{II}}-\mathrm{CO}_{2}{ }^{2-}$ intermediate, which can react with a second molecule of $\mathrm{CO}_{2}$ to yield CO and carbonate (Scheme 1). ${ }^{26}$ Hence, concomitantly one equivalent of $\left[\mathrm{L}^{t \mathrm{tBu}} \mathrm{NiBr}\right]$ should be produced as well as one equivalent of $\left[\mathrm{Cp}_{2} \mathrm{Co}\right] \mathrm{Br}$, which, however, was not isolated. Similar cooperativity of two $\mathrm{Ni}^{\mathrm{I}}$ centres in $\mathrm{CO}_{2}$ activation has been reported utilising different PNP-pincer ligands $\left(\mathrm{L}^{\mathrm{PNP}}\right)$. While in case of a rigid ligand the resulting $\mathrm{L}^{\mathrm{PNP}} \mathrm{Ni}^{\mathrm{II}}-\mathrm{CO}_{2}{ }^{2-}$ $\mathrm{Ni}^{\mathrm{II}} \mathrm{L}^{\mathrm{PNP}}$ appeared stable in contact with excessive $\mathrm{CO}_{2},{ }^{27}$ utilising a more flexible ligand did also lead to concomitant reaction with an additional molecule of $\mathrm{CO}_{2}$, forming a dinuclear $\mathrm{L}^{\mathrm{PNP}} \mathrm{Ni}^{\mathrm{II}}-\mathrm{CO}_{3}-\mathrm{Ni}^{\mathrm{II}} \mathrm{L}^{\mathrm{PNP}}$ unit and $\mathrm{CO}{ }^{28}$ However, no examples have been reported so far where a cooperative activation of $\mathrm{CO}_{2}$ leads to a mononuclear nickel complex, and thus our system is closing this gap. We hypothesise that the presence of the bromido ligand, which remained in the coordination sphere of the reduced nickel centre due to the employment of cobaltocenes as reducing agents (converting into non-coordinating 


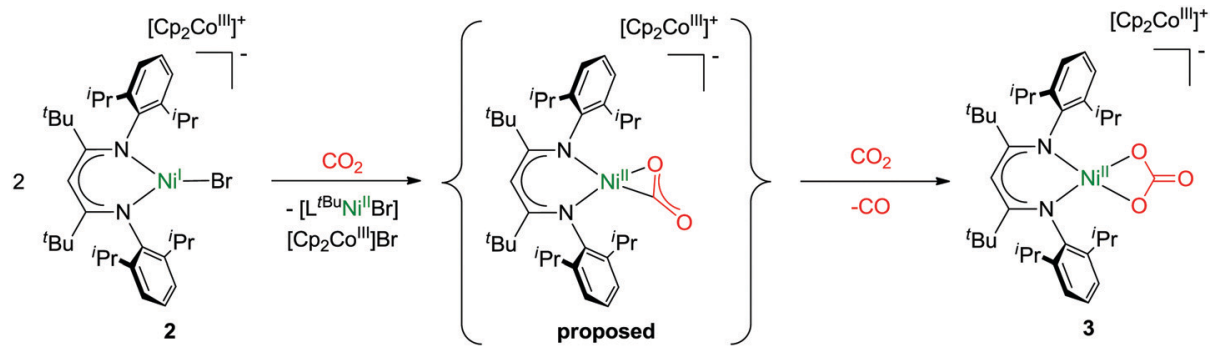

Scheme 1 Reaction of $\mathbf{2}$ with $\mathrm{CO}_{2}$ leads to the formation of $\mathbf{3}$ via a possible $\mathrm{Ni}{ }^{\mathrm{Il}}-\mathrm{CO}_{2}{ }^{2-}$ intermediate.

cations), is decisive for the course of the reaction. If it is not there, as in case of $\left[\mathrm{L}^{t \mathrm{Bu}} \mathrm{Ni}^{\mathrm{I}}-\mathrm{N}_{2}-\mathrm{Ni}^{\mathrm{I}} \mathrm{L}^{t \mathrm{Bu}}\right]$, which in solution exists in a mononuclear form $\left[\mathrm{L}^{t \mathrm{Bu}} \mathrm{Ni}^{\mathrm{I}}-\mathrm{N}_{2}\right]^{17}$ comparable to 2 but with a rather labile co-ligand, oxalate is formed. The differing findings made for 2 , where one coordination site is blocked by the bromido ligand, suggests that formation of oxalate does not occur when only a single coordination site is available for $\mathrm{CO}_{2}$ activation at a nickel(I) centre, presumably as this hinders the fast dimerization of the transient $\mathrm{CO}_{2}{ }^{--}$species, which thus accepts a further electron instead.

Consequently, carbonate is formed from solutions of both $\mathbf{1}$ and $\mathbf{2}$ in contact with $\mathrm{CO}_{2}$ gas, which is notable as solutions of 2 at ambient temperature - unlike those of $\mathbf{1}$ - do not even show an EPR signal indicative for nickel(I) species $\left(\mathrm{Cp}_{2} \mathrm{Co}\right.$ alone does not react with $\mathrm{CO}_{2}$ ). Thus, small molecule activation at reduced metal centres does not necessarily require quantitative electron transfer from the reductant, which should also be considered when discussing oxidation states in biological systems.

Funded by the Deutsche Forschungsgemeinschaft (DFG, German Research Foundation) under Germany's Excellence Strategy - EXC 2008/1 - 390540038. We are grateful to Professor Dr Rainer Winter for helpful discussions.

\section{Conflicts of interest}

There are no conflicts to declare.

\section{References}

1 P. Zimmermann and C. Limberg, J. Am. Chem. Soc., 2017, 139, 4233. 2 B. Horn, C. Limberg, C. Herwig and B. Braun, Chem. Commun., 2013, 49, 10923.

3 B. Horn, S. Pfirrmann, C. Limberg, C. Herwig, B. Braun, S. Mebs and R. Metzinger, Z. Anorg. Allg. Chem., 2011, 637, 1169.

4 S. Pfirrmann, C. Limberg, C. Herwig, R. Stößer and B. Ziemer, Angew. Chem., Int. Ed., 2009, 48, 3357.
5 S. Yao, Y. Xiong, C. Milsmann, E. Bill, S. Pfirrmann, C. Limberg and M. Driess, Chem. - Eur. J., 2010, 16, 436.

6 P. Holze, B. Horn, C. Limberg, C. Matlachowski and S. Mebs, Angew. Chem., Int. Ed., 2014, 53, 2750.

7 S. Yao, E. Bill, C. Milsmann, K. Wieghardt and M. Driess, Angew. Chem., Int. Ed., 2008, 47, 7110.

8 S. Yao and M. Driess, Acc. Chem. Res., 2012, 45, 276.

9 S. Pfirrmann, S. Yao, B. Ziemer, R. Stösser, M. Driess and C. Limberg, Organometallics, 2009, 28, 6855.

10 S. C. Puiu and T. H. Warren, Organometallics, 2003, 22, 3974.

11 E. Kogut, H. L. Wiencko, L. Zhang, D. E. Cordeau and T. H. Warren, J. Am. Chem. Soc., 2005, 127, 11248.

12 M. M. Melzer, S. Jarchow-Choy, E. Kogut and T. H. Warren, Inorg. Chem., 2008, 47, 10187.

13 S. Wiese, P. Kapoor, K. D. Williams and T. H. Warren, J. Am. Chem. Soc., 2009, 131, 18105.

14 P. Zimmermann, D. Ar, M. Rößler, P. Holze, B. Braun, C. Herwig and C. Limberg, Angew. Chem., Int. Ed., DOI: 10.1002/anie.202010180.

15 T. Kothe, U. H. Kim, S. Dechert and F. Meyer, Inorg. Chem., 2020, 59, 14207.

16 H. Stevens, P.-C. Duan, S. Dechert and F. Meyer, J. Am. Chem. Soc., $2020,142,6717$.

17 P. Holze, B. Braun-Cula, S. Mebs and C. Limberg, Z. Anorg. Allg. Chem., 2018, 644, 973.

18 D. V. Yandulov and R. R. Schrock, Inorg. Chem., 2005, 44, 1103.

19 D. Nied, E. Matern, H. Berberich, M. Neumaier and F. Breher, Organometallics, 2010, 29, 6028.

20 D. Braga, O. Benedi, L. Maini and F. Grepioni, J. Chem. Soc., Dalton Trans., 1999, 2611.

21 T. Zhu, Y. Sha, H. A. Firouzjaie, X. Peng, Y. Cha, D. M. M. M. Dissanayake, M. D. Smith, A. K. Vannucci, W. E. Mustain and C. Tang, J. Am. Chem. Soc., 2020, 142, 1083.

22 J. H. Ammeter and J. M. Brom, Chem. Phys. Lett., 1974, 27, 380.

23 J. H. Ammeter and J. D. Swalen, J. Chem. Phys., 1972, 57, 678.

24 B. Horn, C. Limberg, C. Herwig, M. Feist and S. Mebs, Chem. Commun., 2012, 48, 8243.

25 N. J. Hartmann, G. Wu and T. W. Hayton, Chem. Sci., 2018, 9, 6580.

26 P. Zimmermann, S. Hoof, B. Braun-Cula, C. Herwig and C. Limberg, Angew. Chem., Int. Ed., 2018, 57, 7230.

27 C. Yoo and Y. Lee, Angew. Chem., Int. Ed., 2017, 56, 9502.

28 F. Schneck, F. Schendzielorz, N. Hatami, M. Finger, C. Würtele and S. Schneider, Angew. Chem., Int. Ed., 2018, 57, 14482. 